\title{
Attracting User's Attention for Travelling Purposes via Visual Messages
}

\author{
Filip Cvitić \\ University of Zagreb, Croatia \\ filipcvitic@gmail.com \\ Mario Plenković \\ University of Maribor and Alma Mater Europaea, Slovenia \\ mario.plenkovic@almamater.si
}

Visual content has a significant role in attracting users' attention. Platforms such as Facebook, LinkedIn, Twitter, and others have made it possible to access information at the click of a button. If a country, organisation or a company wants to attract tourists or other target groups, social media has considerable influence. People search for information online and analyse the products they desire. Today, social media mainly drives customers' buying behaviour (Manyika et al., 2011; Kumar, Bezawada, Rishika, Janakiraman, \& Kannan, 2016). When promoting content, it is essential to know the target group and to have a visually attractive message. This paper aims to determine the impact of parameters in visual messages that can increase attractiveness and sharing possibilities. The research was aimed at finding the parameters responsible for attracting the users' attention and those responsible for content sharing. To find them, two surveys were done, and quantitative research of those parameters was conducted. After the research, guidelines were set in order to create future content which could have a more significant impact on the target group in creating campaigns on social media.

Keywords: communication science, media, social network, visual communication, visual message, tourism

https://doi.org/10.26493/2335-4194.11.3-18

\section{Introduction: Online Purchasing Decisions Influenced by Social Networks are Becoming Common Practice}

As Tussyadiah (2012) claims, we are merely at the forefront of understanding the value of sharing on mobile network platforms and their impact on buying decisions. It is for this reason that Tussyadiah, Park, and Fesenmaier (2011) suggest the need for more studies to understand better how the advancement of digital media technology impacts these experiences. During the previous two decades, the use of information technology has increased, which is characterised by 'speed, visual impression, ease of use, global availability and maximum efficiency' (Kučiš 2010, p. 21). Social networks determine interactions and influence the spread of ideas and behaviour (Tussyadiah, 2012). Leenders (2002), De Bruyn and Lilien (2008) argues that people are taking into account the opinions and behaviours displayed by significant others, combined with the considerations of other constraints and opportunities, to establish their own opinions and take certain actions accordingly. He labelled this process 'contagion' (Leenders, 2002) or social influence. Wilton, Páez, and Scott (2011) identify that people refer to the experiences of others to make their own decisions when presented with a choice. A social network allows imme- 
diate interactions, which enables the sharing of consumption decisions to generate immediate social reactions and to gain social recognition. Therefore, a social network also represents interconnected conformers seeking recognition from each other (Tussyadiah, 2012).

Today social media mainly drives customers' buying behaviour (Manyika et al., 2011; Kumar et al., 2016). Social network sites have greatly expanded the potential audience beyond traditional family and friends to new, geographically dispersed networks of strangers (Axup \& Viller, 2005; Bamford, Coulton, \& Edwards, 2007; Goodman, 2007; Schmallegger, Carson, \& Jacobsen, 2010). Facebook alone has over 1.5 billion users. More importantly, 70 per cent of users log into Facebook daily (Singh, 2018). As Goodman (2007) noted, networked media has enabled an unlimited number of individuals to potentially join virtual networks and gain valuable market intelligence about places visited. Positive comments on social media increase customers' intentions regarding the purchase, because of risk reduction (Mhlanga \& Tichaawa, 2017). Therefore, the best way to attract consumers' attention is to promote content online. It is necessary to know the target group and tailor the visual message appropriately.

While there is research focusing on the social networks' effect on sharing (Pfeil, Arjan, \& Zaphiris, 2009; Strano, 2008; Trammell \& Keshelashvili, 2005), to date there has been little or no research that addresses the visual parameters that show the relation between visual message's attractiveness and the outcome of sharing in the tourism industry. This paper aims to research the parameters that will show what attracts users' attention the most when seeing a particular ad (visual message) on a social network. In this paper, we further want to show which parameters on an ad (visual message) influence users to share the content that they have seen.

\section{Theoretical Framework: Sharing Content} on Mobile Brings Promotional Potential in Tourism Motivations behind Sharing on Social Networks Visual content has a significant role in attracting users' attention. According to Buscall (Mhlanga \& Tichaawa
2017), visual content gets 94 per cent more total views and is 40 per cent more likely to be shared on social networks then text content. Platforms such as Facebook, LinkedIn, Twitter, and others have made it possible to access information at the click of a button. Sharing is about getting people to see and respond to content. Social media's positive impact is in the distribution of information in the world in which we live. Sixty-two per cent of people get their news from social media, as stated in a study from Pew Research (Gaitho, 2018). As long as the content remains relevant and the need for information still exists, it is always worthwhile for any organisation using social media to keep publishing.

A study by the New York Times Consumer Insight Group shows different motivations that participants have when sharing information on social media: 84 per cent of participants wants to support a cause or issue about which they feel strongly; 94 per cent share to pass valuable information; 49 per cent of these respondents influence action about products by sharing; 68 per cent use social sharing to build image and demonstrate who they are and what they stand for; 78 per cent want to interact, grow, get a sense of fulfilment, nurture relationships and stay in touch with others; 69 per cent want to participate and feel involved in things happening in the world. Additionally, a number of studies (Pfeil et al., 2009; Strano, 2008; Trammell \& Keshelashvili, 2005) suggest that young people use online media to present, manipulate, and/or manage a desired self-image. This is also connected with the theory of self-concept (Grubb \& Grathwohl, 1967), which indicates that consumers value consumption that results in recognition and reinforces reactions from the social network so as to strengthen the conception about themselves. Sharing photographs plays a vital role in image-building. Social networks are particularly effective in image self-presentation because the user can display various types of their online activities and open them to the public if desired (Bortree, 2005; Boyd \& Ellison, 2007). It is, therefore, imperative to know the motivations of the target group with whom you are communicating (Gaitho, 2018). Sharing content can have a significant impact on the real world as well (Kietzmann, Hermkens, McCarthy, \& 
Silvestre, 2011). A tweet by the famous Kylie Jenner ('sooo does anyone else not open Snapchat anymore? Or is it just me ... ugh this is so sad.') caused Snapchat's stocks to drop by 8 per cent, and the company lost 1.7 billion dollars (Večernji list, 2018). When promoting a brand, one should make an effort to understand the target group, their habits, needs, and desires to be able to create a visual message that they would want to share.

\section{Accepting Tourists as Online Users}

Has a Promotional Potential

Whether to attract investors, clients, tourists or other target groups, social media has considerable influence. By analysing the travel industry, the following can be observed. On Facebook, 42 per cent of users share the information about where they travel, 60 per cent factor online opinions into their travel decisions, while 83 per cent trust the recommendations of their families and friends (Alizadeh \& Mat Isa, 2015). From this, it can be seen that virtual communications are often about coordinating physical travel but also enabling conversation between visits and meetings, as have Larsen et al. (2006) stated. Social media empowers customers to actively contribute to content creation and freely communicate in an international and intercultural environment (Alizadeh \& Mat Isa, 2015). Each nation wants to keep its independence and cultural identity, even though globalization has contributed to intensive international contact.

Globalization, however, has not resulted in a unique culture or language. Therefore, professional and international communication in the form of translating promotional tourism messages is an important element of visual communication. In that context, according to Kučiš $(2016,84)$, the 'translator's role is to create new communication value through his work and creativity and thus create a new translated intercultural value.

Therefore, to attract tourists' attention, it is necessary to give them individualised approaches on social networks. Understanding tourists' background improves the chance of attracting their attention; 75 per cent of users who read social sharing comments have clicked on the product link in their friends' Facebook posts, taking them to the tourist service website, and 53 per cent of the users clicked the product website have made a purchase (Bullas, 2012).

People who post images online tend to search for travel information from others who engage in similar activities (Akehurst, 2009). This development has had and will continue to have an impact on destination image development, marketing, and promotion. It will also extend the reach of the information search process to other key informants who have visited the destination, but who do not have any obligation to promote it (Pan, MacLaurin, \& Crotts, 2007). It is important to state that some tourists see consumer-generated content as being more reliable and trustworthy than the content generated for the purpose of advertising (Akehurst, 2009; Mack, Blose, \& Pan, 2008; Zheng \& Gretzel, 2010). Therefore, destination management organizations should consider using social networks in cooperation with networks' influencers or consider other means of attracting on-line users' attention (Akehurst, 2009). They must compete with non-commercial materials posted by online users to the extent that these information providers are the ones with significant influence on the tourist's decision-making behaviour (Akehurst, 2009). Therefore, it is not only necessary to have ad space and to pay for an ad, but also to visually show what product is being sold and to whom. Tourism is said to exist in the interplay between places and stories (Goodman, 2007), with experiences that contain a sense of 'being a particular type of tourist' (McCabe \& Stokoe, 2004). By transforming an intangible experience into something tangible (Osborne, 2000), photographs enable tourists to see the experience more clearly and choose that specific destination as their next one (Schroeder, 2002; Sontag, 1977). Edensor (2000) argues that tourists use photography as a ceremonial form of capturing relationships with each other, places, and other cultures. Likewise, sharing photographs with non-travel party members can enhance the bond between the tourist and the audience. Social networks have transformed this ceremonial form and brought it to the broad online community (Boyd, 2008; Miller \& Edwards, 2007; Qian \& Scott, 2007).

It is also necessary to know how the tourist prod- 
ucts and facilities are different from others who are sending multilingual messages to potential customers.

\section{Understanding Mobile as the Primary Platform for Advertising}

It is rarely possible to expect people to convert the first time they see a visual message on a social network. They need to see it at least seven times before they consider the offer (Halevy, 2018). To achieve the desired action of the banner, one needs to show the same message across different channels (newsletter, different social networks, and searched key words). By doing so, the odds of getting people to respond will be higher (Halevy, 2018).

One important thing has to be considered when creating visual messages for a certain brand: mobile users must not be ignored. Mobile-only internet users outnumber desktop-only users. Globally, mobile devices dominate in terms of total minutes spent online. For example, in the us, 71 per cent of total digital minutes comes from mobile devices. In Indonesia, 91 per cent of time spent online comes from mobile. The average time spent browsing on smartphones per month is 87 hours in the U s, compared to 34 hours on desktops in the same country (De Silva, 2018). Furthermore, 79 per cent of smartphone users have their phone on or near them each hour of the waking day, on which they spend an average of 195 minutes per day (Newlands, 2018). According to Zenith's report, 73 per cent of time spent online in 2018 is predicted to be through a mobile device. Moreover, in 2018, it is expected that 60 per cent of global online advertising spent will come from mobile ads. According to Gartner, more than half of all consumers, by 2018 , will be using mobile devices first for anything they do online (De Silva, 2018). What is more, engagement is higher on mobile devices than on desktop devices. This is because consumers have personal, intimate connections with their mobile devices (Heine, 2014).

The smartphone's capability to link people to remote information, exchanging location-based data and social information has made it a powerful tool for tourists and other users. Smartphones are an inevitable partner for tourism, and the tourism context has become a fertile ground for mobile computing (Chev- erst, Davies, Mitchell, Friday, \& Efstratiou, 2000). The emergence of mobile social networking, which has shifted from desktop computers to mobile computing platforms, offers new sharing capabilities beyond hubs for chat and repositories for photographs. As people are ever more mobile for work and leisure, they increasingly share information and connect with their social network using mobile devices. To make the user experience as uninterrupted as possible, ads for desktop should not need to be recreated for mobile and tablet experience. It is important to consider the best way to showcase content on mobile devises to get a maximum result (English, 2018). So by understanding the target group, the technology they are using, when they are using it and by creating an understandable visual message that is in line with the group's needs, it is possible to make an effective communication campaign.

\section{Hypothesis Development}

Introduction and development of online photo-sharing media has democratized the image creation and dissemination process (Lo, McKercher, Lo, Cheung, \& Law, 2011). Its increasing popularity can turn travel into a stronger self-presentation management tool for users. Web 2.0 will play an important role in tourism marketing, destination image formation, and customer-to-customer communications. Marketers are already applying electronic word-of-mouth (еwом), relationship marketing, and viral marketing (De Bruyn \& Lilien, 2008) in their promotional activities. The approach of viral marketing suggests that marketers can leverage the power of interpersonal networks to promote their products and services, transforming the communication networks into influence networks. Ignoring Web 2.0 as a communication tool will be detrimental to destinations (Lo et al., 2011).

Experience shows that the attractiveness of a visual message increases the users' decision to click on it. If the visual message is more appealing, the user will view it longer and better understand the meaning of the message. The aim of this paper is to discover which parameters influence the attractiveness of the visual message, as well as its possibility of sharing. These results will be used for campaign creation, pub- 
lishing ads and attracting the target group's attention on social networks.

The first hypothesis of this paper is that photographs combined with illustrations are more appealing to users than those which have no illustrations. This hypothesis is derived from the fact that we are surrounded with digital products that use illustrations to better visualize abstract concepts to the user (install, download, update, log in, tag, like, subscribe, etc.). That is way in which we are familiar with the use of illustrations and its extensive use for promotion purposes. The second one is that understandable visual messages are more attractive to the user and therefore have a greater chance to be shared. If this is true, then the user will view the visual message longer. The longer the user views the visual message, the more likely it is for him to understand the content behind it and which action he should take. However, initial attraction must be achieved quickly in order to get users' attention. That sets the third and the final hypothesis: the visual message made with a short message is more attractive than that with the long one. If the visual message is attractive and understandable to the user, it could reach a higher number of people and will have the highest chance to be successful, will be shared by the users, and will have them make the necessary action. Through results, it will be possible to see which parameters contribute to the attractiveness of the researched visual messages.

\section{Research Methodology}

Sample Description

The research was conducted via two separate online questionnaires: the first from July to August 2017 and the second in March 2018. The reason for this was the different goals of each questionnaire. The first questionnaire was done to prove the first hypothesis and the second questionnaire was done to prove the second and third hypotheses. Both questionnaires used a non-probabilistic sample, i.e. a sample that includes a group of individuals available in a certain situation. The respondents represent a target group, i.e. users who use social networks the most. As Lo et al. (2011) showed in their research, $79.5 \%$ of people aged 25 or less and $63.5 \%$ of people aged 26 to 35 have posted pho- tographs online. These groups represent active social network users and are more engaged personally in the information search process. Therefore, the sample is an optimal choice, and it is homogeneous. Each respondent has independently determined the optimal time to take the survey and chose the space in which to take it. The survey started simultaneously, the groups did not have different questions, and they were not separated.

The questionnaires were completed online via the SurveyGizmo service, and its URL links were distributed via the respondents' email addresses. One hundred respondents completed the first questionnaire, 80 of which were in the age range of $26-35$ and 20 in the age range of 19-25. Fifty-seven respondents completed the second questionnaire. Five of them were in the age range of $45+, 30$ in the age range of $30-44$ and 22 in the age range of $16-29 ; 15$ of them were male and 42 were female.

\section{Instrument}

\section{First Questionnaire and Attractiveness Research}

The method used in this research is an online survey. The target group were people aged 19-35 who use smartphones, frequently consume multimedia content, and are constantly online. The visual message used in this research was designed with sea, vacation, and relaxation in mind. As active vacations are important to young people, displaying motifs for vacation and relaxation can attract their attention.

In order to determine the results of whether the addition of an illustration in a photograph impacts the attractiveness of a visual message, it was necessary to determine the following parameters:

- How many people does the visual message contain (from o to 3 )?

- Does the visual message have an illustration or not, does the visual message have a product or not and does it have a simple or a complex background?

Each variable will be permuted with another variable in order to determine which element would impact the attractiveness of the message the most. In this way, variables which contribute to the attractiveness of 


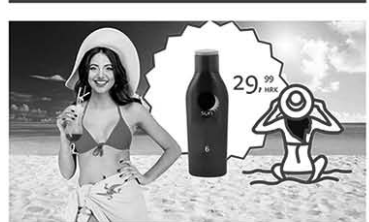

Figure 1.

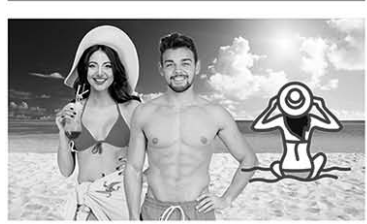

Figure 5.

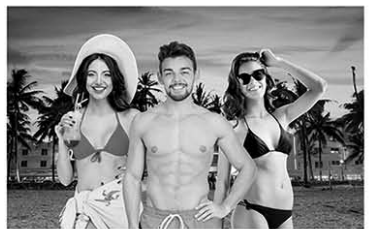

Figure 9.

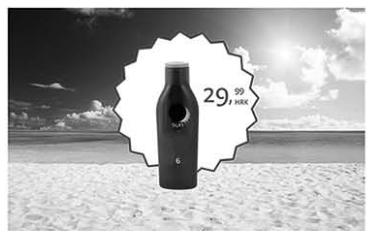

Figure 13.

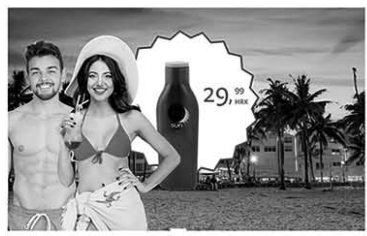

Figure 17.

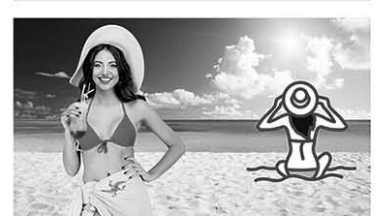

Figure 2.

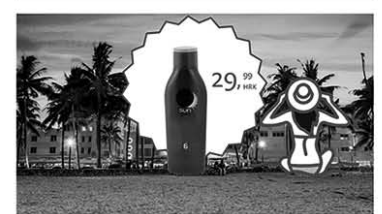

Figure 6.

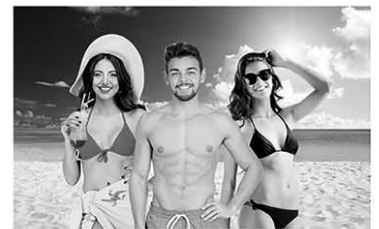

Figure 10 .

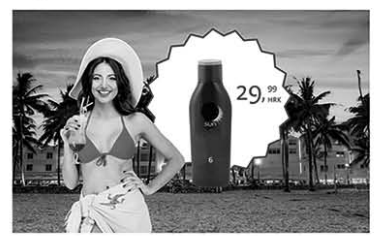

Figure 14.

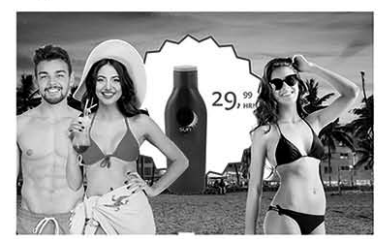

Figure 18.

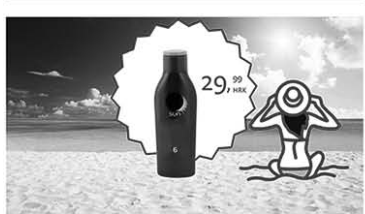

Figure 3.

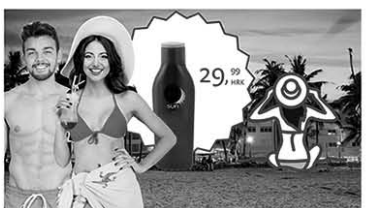

Figure 7.

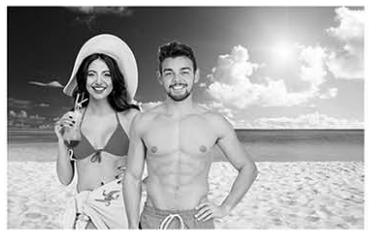

Figure 11 .

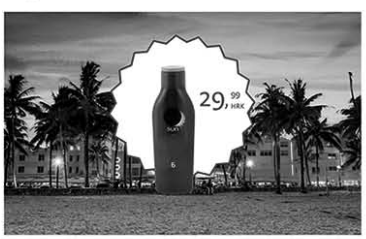

Figure 15.

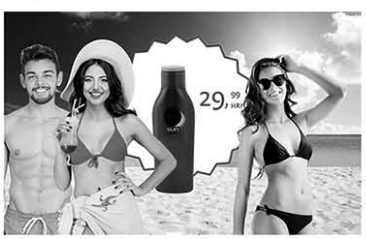

Figure 19.

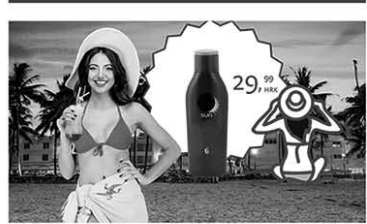

Figure 4.

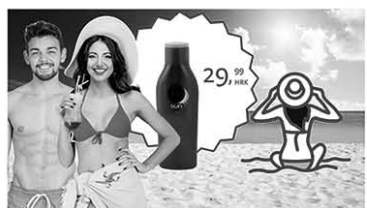

Figure 8.

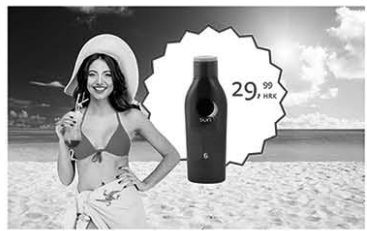

Figure 12.

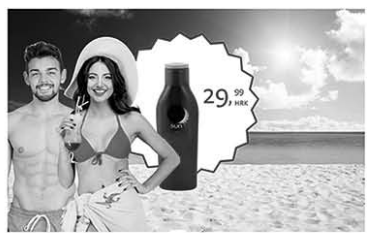

Figure 16.

Figure 1 Figures Used in the First Questionnaire

a visual message (illustration, number of people, background, and element composition) were researched. There were 19 figures for which the respondents had to answer the given questions (see Figure 1).

To get the most data from the answers, a 5-point Likert scale was used in order to determine the inclination to one type of question or another. For each figure, each user was asked the same question. The questions for each figure were the following.

1. Grade the attractiveness of this visual message (1 - I don't like it, 5 - I like it a lot).

2. What is the first thing you notice in the visual

message: (a) the illustration, (b) the people, (c) the background, (d) the product, (e) the element composition?

3. Determine what is bothering you in the visual message: (a) the illustration, (b) the people, (c) the background, (d) the product, (e) the element composition.

4. Would you forward the previous content to your friends ( 1 - No, 5 - Yes).

5. Would you like to research the content further on the internet ( 1 - No, 5 - Yes). 


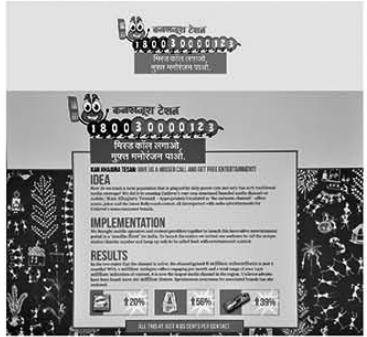

Figure 1.

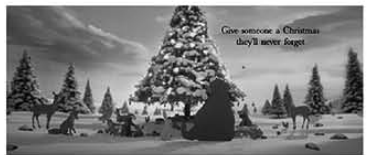

Figure 5.

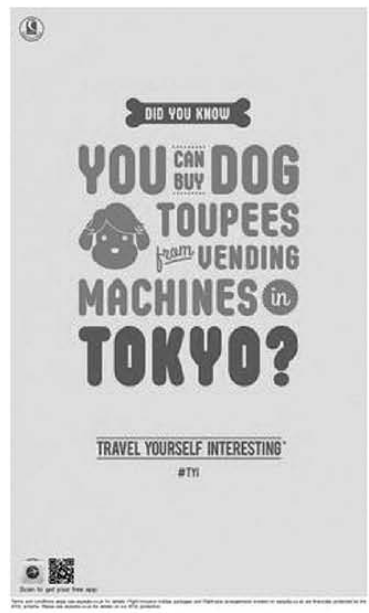

Figure 9.

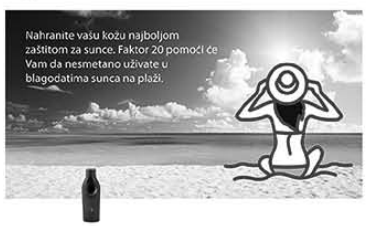

Figure 10.

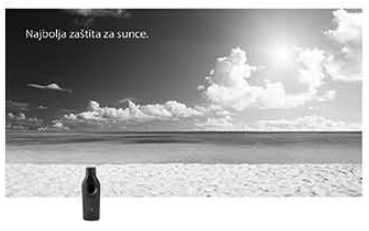

Figure 14 .

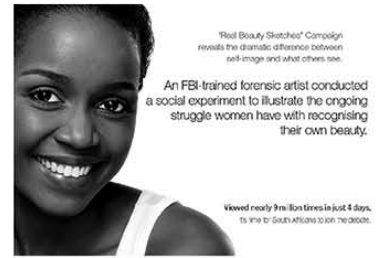

Figure 2.

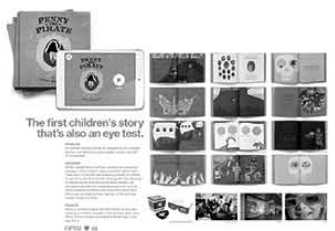

Figure 6.

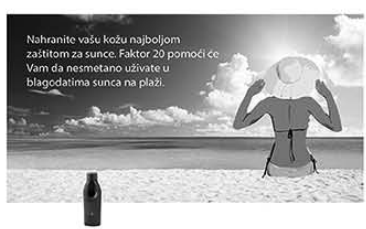

Figure 11.

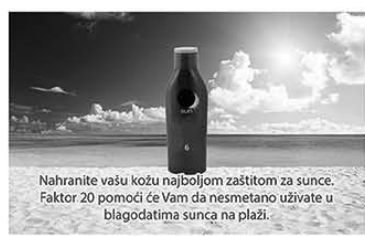

Figure 15.

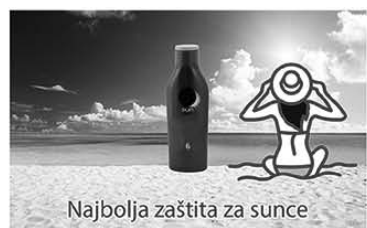

Figure 19.

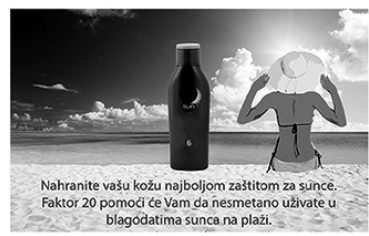

Figure 18.

Figure 2 Figures Used in the Second Questionnaire

\section{Second Questionnaire and Sharing Research}

The method used in this part of the research is also a questionnaire. The target group is the same as for the

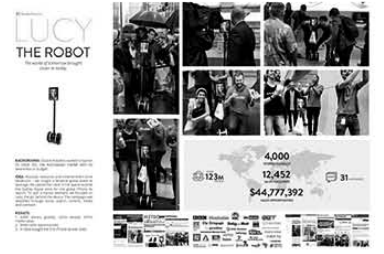

Figure 3.

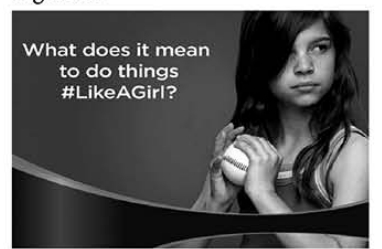

Figure 7.
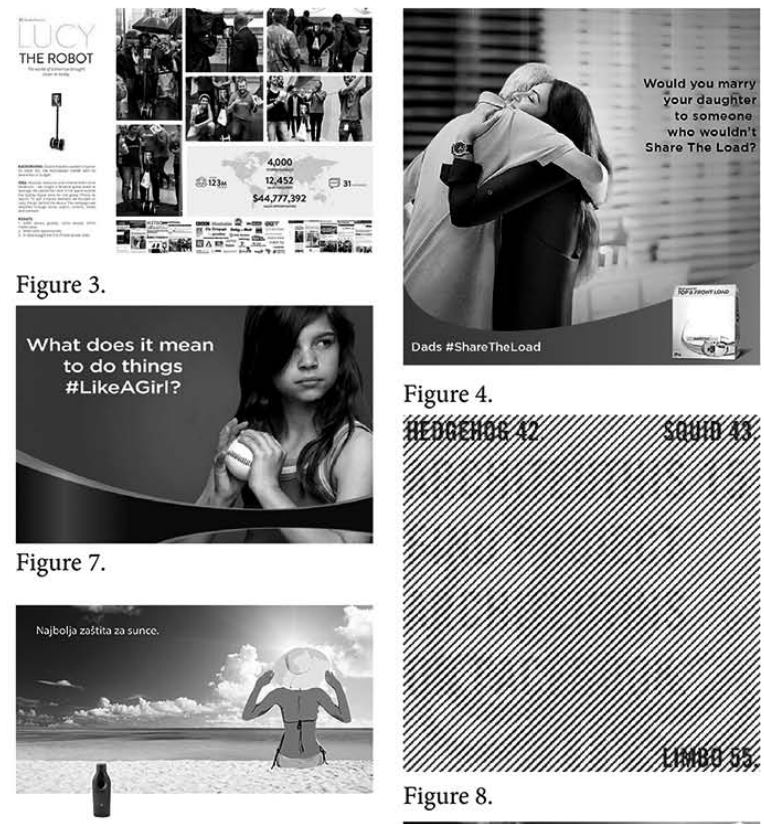

Figure 4.

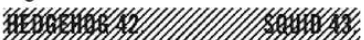

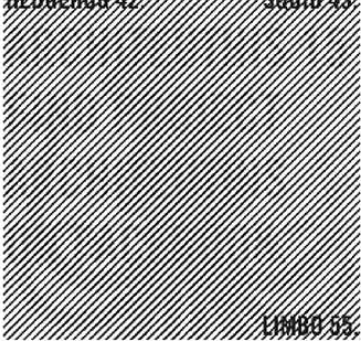

Figure 8 .

Figure 12.
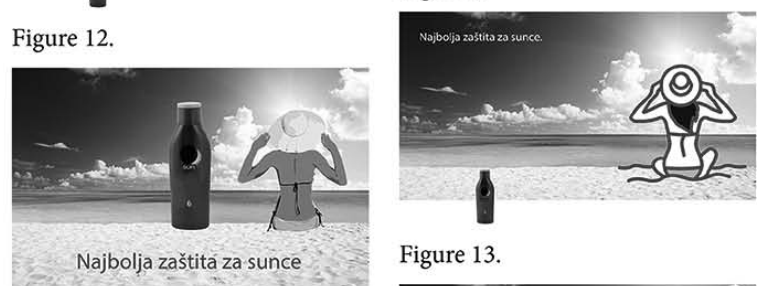

Figure 13.

Figure 16.
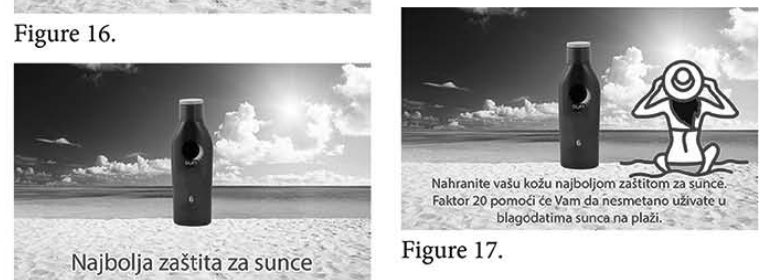

Figure 17.

Figure 20.

first one. The questionnaire consisted of two groups of figures (most efficient campaign group and research campaign group). The first group consisted of nine fig- 

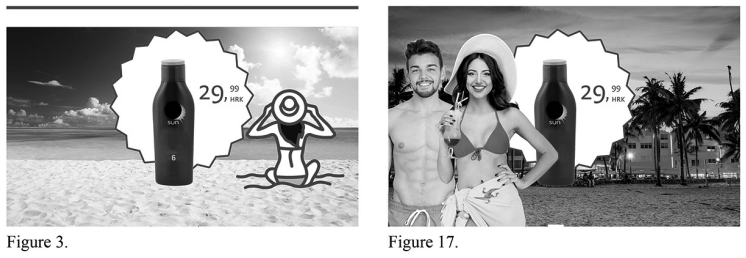

Figure 3 The Most Attractive Visual Message is the Figure $\mathrm{C}$, and the Least Attractive One is Figure $\mathrm{R}$

ures from the top three most efficient marketing campaigns in 2015, 2016. and 2017 according to WARC, a marketing intelligence service, using their global index of effectiveness in advertising. The second group consisted of a research campaign (11 ads) whose figures are a refinement of the figures from the first questionnaire. The figures in the research campaign were prepared after the results from the first questionnaire were known. Variables that contributed to visual messages' attractiveness in the first questionnaire were used to set 11 figures in the research campaign. Those variables (background, illustration), chosen from the first questionnaire based on the results from Table 1, were further altered with the additional ones - length of a message, complexity of illustration, product size. In this way, 11 figures were formed. The goal of the research was to get the answers for the second and third hypotheses set out in this paper. There were 20 different ads (figures) in total (see Figure 2).

The variables that were researched are: ad attractiveness, willingness to share, campaign type (questions 1-59 refer to the most efficient campaigns, questions 60-125 refer to the research campaign), message length, message comprehensibility, complexity of illustration, product size, products role (primary or secondary). In this research, picture size as well as the platform (desktop or mobile) was not taken into account because the goal was to research the variables within the format.

There were 125 questions in total. The first five questions had the goal of describing the respondent (travel preferences and factors that help respondent choose a travel destination, gender, age, the purpose for which the respondent uses his smartphone). Each respondent had to answer six questions for each figure:
1. Do you find the visual message attractive ( $1-\mathrm{No}$, 5 - Yes)?

2. Do you find its message understandable ( $1-\mathrm{No}$, 5 - Yes)?

3. The shown message is: $(1-$ too short, 5 - too long).

4. Do you understand which product is being promoted $(1-$ No, 5 - Yes)?

5. The size of the product is: $(1-$ too small, 5 - too big).

6. Would you share the content that you have seen $(1$ - No, 5 - Yes)?

A 5-point Likert scale was used to determine the inclination to one type of question or another. The responses from the respondents are shown in Table 1.

Based on the second part of the research, a statistical analysis was carried out and the answers between the most efficient campaigns and the research campaign were compared. With the analysis, the possibility for sharing the visual message is explored.

\section{Results and Hypotheses Testing}

The results from the conducted questionnaires are the following.

First Questionnaire. For Figure C, most respondents gave the highest grades for the following questions: 'How attractive is the previous content?' (10 respondents, average grade 2.9), 'Would you forward the previous content to your friends?' ( 15 respondents, average grade 2.25). In total, 15 respondents gave the grade of 4 out of 5 for Figure C.

In contrast, the least attractive visual message was Figure R, for which 60 respondents gave the lowest grade (average grade 1.7). The lowest grade for the questions 'How attractive is the previous content?', 'Would you forward the previous content to your friends' (average grade 1.4) and 'Would you like to research the content more on the internet?' was given to Figure R (7o respondents gave the grade 1 out of 5) (see Figure 3). From this, it is clear that the most attractive visual message has the greatest probability of being shared. At the same time, the least attractive visual message has the lowest probability of being shard. 
Table 1 Answers from the Respondents

\begin{tabular}{|c|c|c|c|c|c|c|}
\hline \multirow[t]{2}{*}{ Figure } & \multicolumn{6}{|c|}{ Question } \\
\hline & Q1 & Q2 & A 1 & Q3 & Q4 & A 2 \\
\hline \multirow[t]{6}{*}{ A } & 30 & 45 & 1 & 20 & 20 & $\mathrm{a}$ \\
\hline & 20 & 35 & 2 & o & o & b \\
\hline & 50 & 15 & 3 & 30 & 20 & c \\
\hline & 0 & 5 & 4 & 0 & 10 & d \\
\hline & 0 & o & 5 & 50 & 40 & e \\
\hline & I & I & I & I & 10 & $\mathrm{f}$ \\
\hline Average & 2.2 & 1.8 & & I & I & \\
\hline \multirow[t]{6}{*}{ B } & 20 & 40 & 1 & 30 & 20 & $\mathrm{a}$ \\
\hline & 30 & 25 & 2 & 50 & 70 & $\mathrm{~b}$ \\
\hline & 20 & 25 & 3 & 20 & o & c \\
\hline & 30 & 10 & 4 & 0 & o & d \\
\hline & 0 & o & 5 & 0 & o & e \\
\hline & I & I & I & I & 10 & $\mathrm{f}$ \\
\hline Average & 2.6 & 2.05 & & I & I & \\
\hline \multirow[t]{6}{*}{ C } & 10 & 35 & 1 & 40 & 10 & $\mathrm{a}$ \\
\hline & 30 & 20 & 2 & o & 0 & b \\
\hline & 30 & 30 & 3 & 20 & 20 & c \\
\hline & 20 & 15 & 4 & o & o & d \\
\hline & 10 & o & 5 & 40 & 30 & e \\
\hline & I & I & I & I & 40 & $\mathrm{f}$ \\
\hline Average & 2.9 & 2.25 & & I & I & \\
\hline \multirow[t]{6}{*}{$\mathrm{D}$} & 40 & 50 & 1 & o & 20 & $\mathrm{a}$ \\
\hline & 30 & 35 & 2 & 30 & 0 & $\mathrm{~b}$ \\
\hline & 30 & 15 & 3 & 60 & 50 & c \\
\hline & 0 & o & 4 & 0 & o & d \\
\hline & 0 & 0 & 5 & 10 & 20 & e \\
\hline & I & I & I & I & 10 & $\mathrm{f}$ \\
\hline Average & 1.9 & 1.65 & & I & I & \\
\hline
\end{tabular}

Continued in the next column

It can further be seen that the most attractive visual message is the one that has a combination of illustrations and photographs. From the visual messages in which an illustration of a woman's back is shown, the most attractive is the one in Figure C. As seen from Table 1, the illustration of a woman's back attracted respondents' attention the most (40 of them) in Figure
Table 1 Continued

\begin{tabular}{|c|c|c|c|c|c|c|}
\hline \multirow[t]{2}{*}{ Figure } & \multicolumn{6}{|c|}{ Question } \\
\hline & Q1 & Q2 & A 1 & Q3 & Q4 & A 2 \\
\hline \multirow[t]{6}{*}{ E } & 50 & 60 & 1 & o & 10 & $\mathrm{a}$ \\
\hline & 30 & 10 & 2 & 100 & 80 & $\mathrm{~b}$ \\
\hline & 10 & 25 & 3 & 0 & o & c \\
\hline & 10 & 5 & 4 & 0 & 0 & d \\
\hline & 0 & o & 5 & o & 0 & e \\
\hline & I & I & I & I & 10 & $\mathrm{f}$ \\
\hline Average & 1.8 & 1.75 & & 1 & I & \\
\hline \multirow[t]{6}{*}{$\mathrm{F}$} & 30 & 60 & 1 & 30 & 10 & $\mathrm{a}$ \\
\hline & 60 & 25 & 2 & o & o & $\mathrm{b}$ \\
\hline & 0 & 15 & 3 & 70 & 60 & c \\
\hline & 10 & 0 & 4 & 0 & 0 & d \\
\hline & 0 & 0 & 5 & 0 & 20 & e \\
\hline & I & I & I & 1 & 10 & $\mathrm{f}$ \\
\hline Average & 1.9 & 1.55 & & I & I & \\
\hline \multirow[t]{6}{*}{ G } & 50 & 70 & 1 & o & o & $\mathrm{a}$ \\
\hline & 30 & 25 & 2 & 80 & 60 & $\mathrm{~b}$ \\
\hline & 20 & 5 & 3 & 0 & 0 & c \\
\hline & 0 & 0 & 4 & o & o & d \\
\hline & 0 & 0 & 5 & 10 & 30 & e \\
\hline & I & I & I & 1 & 10 & $\mathrm{f}$ \\
\hline Average & 1.7 & 1.35 & & I & I & \\
\hline \multirow[t]{6}{*}{$\mathrm{H}$} & 30 & 40 & 1 & 10 & 30 & $\mathrm{a}$ \\
\hline & 20 & 35 & 2 & 70 & 50 & $\mathrm{~b}$ \\
\hline & 50 & 25 & 3 & 10 & & c \\
\hline & 0 & 0 & 4 & 0 & & $\mathrm{~d}$ \\
\hline & 0 & 0 & 5 & 10 & 10 & e \\
\hline & I & I & I & I & 10 & $\mathrm{f}$ \\
\hline Average & 2.2 & 1.85 & & 1 & I & \\
\hline
\end{tabular}

Continued in the next column

C. The parameters element composition (40 of them) and background (20 of them) have also attracted respondents' attention the most in Figure C. Figure $\mathrm{C}$ is also the figure for which most of the respondents (40 of them) said that nothing bothered them in that visual message. Although the possibility of sharing content on social media is 40 percent (Mhlanga \& Tichaawa 
Table 1 Continued

\begin{tabular}{|c|c|c|c|c|c|c|}
\hline \multirow[t]{2}{*}{ Figure } & \multicolumn{6}{|c|}{ Question } \\
\hline & Q1 & Q2 & A 1 & Q3 & Q4 & A 2 \\
\hline \multirow[t]{6}{*}{ I } & 40 & 50 & 1 & 10 & 30 & \\
\hline & 10 & 30 & 2 & 70 & 50 & $b$ \\
\hline & 40 & 10 & 3 & 10 & 0 & c \\
\hline & 10 & 5 & 4 & o & o & $\mathrm{d}$ \\
\hline & o & o & 5 & 10 & 10 & $\mathrm{e}$ \\
\hline & I & I & I & I & 10 & 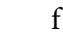 \\
\hline Average & 2.2 & 1.6 & & I & 1 & \\
\hline \multirow[t]{6}{*}{$\mathrm{J}$} & 30 & 50 & 1 & o & o & \\
\hline & 10 & 15 & 2 & 100 & 20 & b \\
\hline & 40 & 20 & 3 & o & 10 & c \\
\hline & 20 & 15 & 4 & o & o & d \\
\hline & o & 0 & 5 & o & 30 & $\mathrm{e}$ \\
\hline & I & I & I & I & 40 & 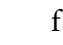 \\
\hline Average & 2.5 & 2 & & I & 1 & \\
\hline \multirow[t]{6}{*}{$\mathrm{K}$} & 40 & 60 & 1 & o & o & a \\
\hline & 20 & 20 & 2 & 60 & 20 & $\mathrm{~b}$ \\
\hline & 30 & 10 & 3 & 40 & 0 & c \\
\hline & 10 & 10 & 4 & o & o & d \\
\hline & o & o & 5 & o & 30 & e \\
\hline & I & I & I & I & 50 & \\
\hline Average & 2.1 & 1.7 & & I & 1 & \\
\hline \multirow[t]{6}{*}{$\mathrm{L}$} & 20 & 45 & 1 & o & o & 9 \\
\hline & 10 & 25 & 2 & 80 & 40 & $\mathrm{~b}$ \\
\hline & 50 & 30 & 3 & 10 & 0 & c \\
\hline & 20 & o & 4 & o & o & d \\
\hline & o & o & 5 & 10 & 40 & $\mathrm{e}$ \\
\hline & I & I & I & I & 20 & 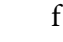 \\
\hline Average & 2.7 & 1.85 & & I & 1 & \\
\hline
\end{tabular}

Continued in the next column

2017), this does not guarantee that anybody who looks at the ad will share it with his friends. It is essential to know your target group's needs, wishes and to know when to offer them the product or service. Not only is this information and the message being communicated to the users important, but it is also important to know how to show the message visually. It must be
Table 1 Continued

\begin{tabular}{|c|c|c|c|c|c|c|}
\hline \multirow[t]{2}{*}{ Figure } & \multicolumn{6}{|c|}{ Question } \\
\hline & Q1 & Q2 & A 1 & Q3 & Q4 & A 2 \\
\hline \multirow[t]{6}{*}{ M } & 30 & 40 & 1 & 40 & 20 & $\mathrm{a}$ \\
\hline & 20 & 30 & 2 & 20 & o & $\mathrm{b}$ \\
\hline & 40 & 30 & 3 & 20 & 10 & C \\
\hline & 10 & 0 & 4 & o & o & d \\
\hline & o & 0 & 5 & 20 & 40 & $\mathrm{e}$ \\
\hline & I & I & I & I & 30 & $\mathrm{f}$ \\
\hline Average & 2.3 & 1.9 & & I & I & \\
\hline \multirow[t]{6}{*}{$\mathrm{N}$} & 30 & 65 & 1 & 50 & 30 & $\mathrm{a}$ \\
\hline & 40 & 25 & 2 & 0 & o & $\mathrm{b}$ \\
\hline & 30 & 10 & 3 & o & 10 & c \\
\hline & o & 0 & 4 & 10 & o & d \\
\hline & o & o & 5 & 40 & 20 & $\mathrm{e}$ \\
\hline & I & I & I & I & 40 & $\mathrm{f}$ \\
\hline Average & 2 & 1.45 & & I & I & \\
\hline \multirow[t]{6}{*}{$\mathrm{O}$} & 50 & 60 & 1 & 10 & 20 & $\mathrm{a}$ \\
\hline & 30 & 20 & 2 & 40 & o & $\mathrm{b}$ \\
\hline & 10 & 20 & 3 & 50 & 70 & c \\
\hline & 10 & o & 4 & o & o & d \\
\hline & o & 0 & 5 & o & 10 & $\mathrm{e}$ \\
\hline & I & I & I & I & o & $\mathrm{f}$ \\
\hline Average & 1.8 & 1.6 & & I & I & \\
\hline \multirow[t]{6}{*}{$\mathrm{P}$} & 30 & 60 & 1 & 60 & 30 & $\mathrm{a}$ \\
\hline & 30 & 20 & 2 & o & o & $\mathrm{b}$ \\
\hline & 40 & 20 & 3 & 30 & 50 & $\mathrm{c}$ \\
\hline & o & 0 & 4 & o & o & $\mathrm{d}$ \\
\hline & o & 0 & 5 & 10 & 10 & $\mathrm{e}$ \\
\hline & l & I & I & I & 10 & $\mathrm{f}$ \\
\hline Average & 2.1 & 1.6 & & I & I & \\
\hline
\end{tabular}

Continued in the next column

meaningful to them and it must be something they want, something they search for, something they need. If this is done correctly, the target group will be able to instantly and unequivocally understand the visual message.

It can be seen in Figure 4 (p. 14) the majority of the respondents would not want to forward the visual 
Table 1 Continued

\begin{tabular}{|c|c|c|c|c|c|c|}
\hline \multirow[t]{2}{*}{ Figure } & \multicolumn{6}{|c|}{ Question } \\
\hline & Q1 & Q2 & A 1 & Q3 & Q4 & A 2 \\
\hline \multirow[t]{6}{*}{$\mathrm{R}$} & 60 & 70 & 1 & 20 & 40 & a \\
\hline & 10 & 20 & 2 & 80 & 20 & b \\
\hline & 30 & 10 & 3 & o & o & c \\
\hline & o & 0 & 4 & o & o & d \\
\hline & o & o & 5 & o & 40 & $\mathrm{e}$ \\
\hline & 1 & I & I & I & o & $\mathrm{f}$ \\
\hline Average & 1.7 & 1.4 & & / & I & \\
\hline \multirow[t]{6}{*}{ S } & 50 & 70 & 1 & o & 10 & $\mathrm{a}$ \\
\hline & 20 & 20 & 2 & 60 & o & $\mathrm{b}$ \\
\hline & 20 & 10 & 3 & 40 & 40 & c \\
\hline & 10 & 0 & 4 & o & 0 & $\mathrm{~d}$ \\
\hline & o & o & 5 & o & 50 & e \\
\hline & 1 & I & I & I & o & $\mathrm{f}$ \\
\hline Average & 1.9 & 1.4 & & I & I & \\
\hline \multirow[t]{6}{*}{$\mathrm{T}$} & 50 & 60 & 1 & o & 10 & a \\
\hline & 10 & 10 & 2 & 100 & 30 & $\mathrm{~b}$ \\
\hline & 30 & 30 & 3 & 0 & 20 & c \\
\hline & 10 & o & 4 & 0 & o & d \\
\hline & o & o & 5 & o & 40 & $\mathrm{e}$ \\
\hline & I & I & I & I & 0 & $\mathrm{f}$ \\
\hline Average & 2 & 1.7 & & I & I & \\
\hline
\end{tabular}

Notes Questions: Q1 - Grade the attractiveness of the previous visual message (1 - I don't like it, 5 - I like it a lot). Q2 - Would you forward the previous content to your friends (1 - No, 5 - Yes)? Q3 - What was the first thing you noticed on a visual message? Q4 - Determine what's bothering you on a visual message. A2 - (a) the illustration, (b) the people, (c) the background, (d) the product, (e) the element composition, (f) nothing is bothering me.

message (of the displayed figures) to their friends. For the most attractive figure, the number of those who would want to share the visual message was the highest (with an average grade of 2.25). For the respondents who found the content visually attractive, which also implies that they understand the visual message, in 62.5 percent of the cases they would want to share the same content with friends. It can be concluded that attractive content increases the possibility of its be-
Table 2 Average Grade Values from all 57 Respondents from Questions Q6 to Q125

\begin{tabular}{|c|c|c|c|c|c|c|}
\hline \multirow[t]{2}{*}{ Figure } & \multicolumn{6}{|c|}{ Question } \\
\hline & 1 & 2 & 3 & 4 & 5 & 6 \\
\hline \multirow[t]{2}{*}{$1 \mathrm{~A}$} & Q6 & Q7 & Q 8 & Q9 & Q10 & Q11 \\
\hline & 2 & 2 & 4 & 2 & 2 & 1 \\
\hline \multirow[t]{2}{*}{$2 \mathrm{~A}$} & Q12 & Q13 & Q14 & Q15 & Q16 & Q17 \\
\hline & 4 & 4 & 3 & 4 & 3 & 3 \\
\hline \multirow[t]{2}{*}{$3 \mathrm{~A}$} & Q18 & Q19 & Q20 & Q21 & Q22 & Q23 \\
\hline & 3 & 3 & 4 & 3 & 3 & 2 \\
\hline \multirow[t]{2}{*}{$4 \mathrm{~A}$} & Q24 & Q25 & Q26 & Q27 & Q28 & Q29 \\
\hline & 3 & 4 & 3 & 4 & 3 & 3 \\
\hline \multirow[t]{2}{*}{$5 \mathrm{~A}$} & Q30 & Q31 & Q32 & Q33 & Q34 & Q35 \\
\hline & 4 & 3 & 3 & 2 & 2 & 3 \\
\hline \multirow[t]{2}{*}{$6 \mathrm{~A}$} & Q36 & Q37 & Q38 & Q39 & Q40 & Q41 \\
\hline & 3 & 4 & 3 & 4 & 3 & 3 \\
\hline \multirow[t]{2}{*}{$7 \mathrm{~A}$} & $\mathrm{Q} 42$ & Q43 & Q44 & Q45 & Q46 & Q47 \\
\hline & 4 & 4 & 3 & 4 & 3 & 3 \\
\hline \multirow[t]{2}{*}{$8 \mathrm{~A}$} & Q48 & Q49 & Q50 & Q51 & Q52 & Q53 \\
\hline & 2 & 1 & 2 & 1 & 2 & 2 \\
\hline \multirow[t]{2}{*}{$9 \mathrm{~A}$} & Q54 & Q55 & Q56 & Q57 & Q58 & Q59 \\
\hline & 3 & 3 & 3 & 3 & 2 & 3 \\
\hline \multirow[t]{2}{*}{$10 \mathrm{~A}$} & Q60 & Q61 & Q62 & Q63 & Q64 & Q65 \\
\hline & 3 & 4 & 3 & 5 & 3 & 2 \\
\hline \multirow[t]{2}{*}{$11 \mathrm{~A}$} & Q66 & Q67 & Q68 & Q69 & Q70 & Q71 \\
\hline & 3 & 4 & 4 & 5 & 3 & 2 \\
\hline \multirow[t]{2}{*}{$12 \mathrm{~A}$} & Q72 & Q73 & Q74 & Q75 & Q76 & Q77 \\
\hline & 3 & 5 & 3 & 4 & 3 & 3 \\
\hline \multirow[t]{2}{*}{$13 \mathrm{~A}$} & Q78 & Q79 & $\mathrm{Q} 80$ & $\mathrm{Q} 81$ & $\mathrm{Q} 82$ & Q83 \\
\hline & 3 & 4 & 3 & 5 & 3 & 2 \\
\hline \multirow[t]{2}{*}{$14 \mathrm{~A}$} & $\mathrm{Q} 84$ & $\mathrm{Q} 85$ & Q 86 & Q87 & Q 88 & Q89 \\
\hline & 3 & 4 & 2 & 4 & 2 & 2 \\
\hline
\end{tabular}

Continued in the next column

ing shared on social networks. Therefore, it is possible to make a relation to Buscall's research (Mhlanga \& Tichaawa 2017); 31.6 percent of the respondents from the research in this paper thought that the content was attractive. From the users who considered the visual message attractive, 62.5 percent would share the con- 
Table 2 Continued

\begin{tabular}{lrrrrrr}
\hline Figure & \multicolumn{7}{c}{ Question } & & \\
\cline { 2 - 7 } 15A & Q90 & Q91 & Q92 & Q93 & Q94 & Q95 \\
& 3 & 4 & 4 & 5 & 4 & 2 \\
\hline 16A & Q96 & Q97 & Q98 & Q99 & Q100 & Q101 \\
& 3 & 4 & 3 & 5 & 4 & 2 \\
\hline 17A & Q102 & Q103 & Q104 & Q105 & Q106 & Q107 \\
& 2 & 4 & 4 & 5 & 4 & 2 \\
\hline 18A & Q108 & Q109 & Q110 & Q111 & Q112 & Q113 \\
& 3 & 4 & 4 & 4 & 4 & 2 \\
\hline 19A & Q114 & Q115 & Q116 & Q117 & Q118 & Q119 \\
& 3 & 4 & 3 & 5 & 4 & 2 \\
\hline $20 A$ & Q120 & Q121 & Q122 & Q123 & Q124 & Q125 \\
& 3 & 4 & 3 & 4 & 4 & 2 \\
\hline
\end{tabular}

Notes Each image had the same questions in the following order: 1 . Do you find the visual message attractive? (1 - No, 5 - Yes) - Q6, Q12, Q18, Q24, Q30, Q36, Q42, Q48, Q54, Q60, Q66, Q72, Q78, Q84, Q90, Q96, Q102, Q108, Q114, Q120, 2. Do you find its message understandable? (1 - No, 5 - Yes) - Q7, Q13, Q19, Q25, Q31, Q37, Q43, Q49, Q55, Q61, Q67, Q73, Q79, Q85, Q91, Q97, Q103, Q109, Q115, Q121, 3. The shown message is: (1 - too short, 5 - too long) - Q8, Q14, Q20, Q26, Q32, Q38, Q44, Q50, Q56, Q62, Q68, Q74, Q80, Q86, Q92, Q98, Q104, Q110, Q116, Q122, 4. Do you understand which product is being promoted? (1 No, 5 - Yes) - Q9, Q15, Q21, Q27, Q33, Q39, Q45, Q51, Q57, Q63, Q69, Q75, Q81, Q87, Q93, Q99, Q105, Q111, Q117, Q123, 5. The size of the product is: $(1-$ too small, 5 - too big) - Q10, Q16, Q22, Q28, Q34, Q40, Q46, Q52, Q58, Q64, Q70, Q76, Q82, Q88, Q94, Q100, Q106, Q112, Q118, Q124, 6. Would you share the content that you have seen? (1 - No, 5 - Yes) - Q11, Q17, Q23, Q29, Q35, Q41, Q47, Q53, Q59, Q65, Q71, Q77, Q83, Q89, Q95, Q101, Q107, Q113, Q119, Q125. A 5point Likert scale was used in order to determine the inclination to one type of question or another.

tent with friends. That means that 19.75 percent of social media users who saw the content, and fond it visually attractive, would want to share it with others. Because visual messages are viewed 94 percent more than plain text messages on social networks, it can be expected that 18.57 percent of users will share the content.

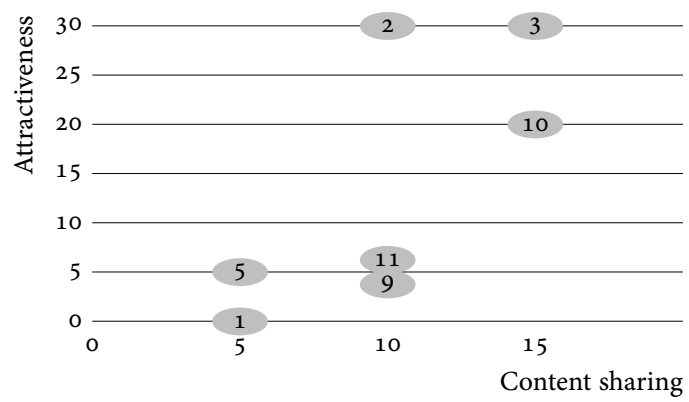

Figure 4 Displaying Figures Which the Respondents Would Want to Share with Friends

When observing figures in total, the following can be seen. From all the variables from all the figures that attracted the respondents' attention, element composition attracted their attention the least. In response to the task 'Determine what bothers you on the visual message' most of the respondents wrote that the people those who bothered them on the shown visual messages. Interestingly enough, the illustration was the variable that bothered the respondents the least.

Because people are those who bothered the respondents in the visual message and decreased the overall attractiveness, as seen from the results in Table 1, they were left out in the second research.

Second Questionnaire. Several statistical analyses were conducted to research the relation between the attractiveness of a visual message and its possibility of being shared.

The first analysis researched the relation between the attractiveness and the possibility of being shared. More precisely, the relation between the questions ' Do you find the visual message attractive?' and 'Would you share the content that you have seen?' was researched. This research was done with both groups (the most efficient campaigns and the research campaign). It has shown there is a statistically significant correlation between ad attractiveness and willingness to share it.

The second analysis was similar to the first one. The research was about checking the relation of the attractiveness and the possibility of sharing between two groups (the most efficient campaigns and the research campaign). 
The second analysis has shown that the correlation is statistically significant no matter which campaign type was analysed. The respondents did not make any difference between the two researched groups (1st group - the most efficient campaigns and 2nd group - research campaign). This means that visual style is not the only thing that affects the overall effectiveness of a campaign.

The third analysis researched the relation of the attractiveness of a visual message and the length of a message. This analysis explored the relation between the following questions: 'Do you find the visual message attractive?' and 'The shown message is: ( 1 - too short, 5 - too long).' It has shown that there is no statistically significant correlation between ad attractiveness and message length.

The fourth analysis researched the relation between the understanding of a visual message and the sharing of that message. The aim of this research was to determine whether an understandable visual message would be shared more than the one that was not understandable. The fourth analysis explored the relation between two questions: 'Do you find its message understandable?' and 'Would you share the content that you have seen?' This analysis has shown that there is a statistically significant correlation between message comprehensibility and willingness to share. Regardless of whether the group was the first one (the most efficient campaigns) or the second one (the research campaign), the respondents wanted to share the visual messages which they understood.

Kolmogorov-Smirnov tests showed that ratings on each item were not normally distributed (all $p<0.001$ ), and therefore nonparametric statistical analyses were used. The degree of association between dependent variables was calculated using Spearman's correlation analyses and a partial correlation analysis. There was a positive relationship between the ad attractiveness and willingness to share, $r s=0.616, p<0.001$. This correlation remained significant even when campaign type was partially out, $r=0.629, p<0.001$. However, there was no significant relationship between the ad attractiveness and message length, $r s=0.059, p=0.046$. Willingness to share was also correlated with message comprehensibility, $r s=0.264, p<0.001$, indicating that understandable ads are more likely to be shared.

Based on the results from the second questionnaire the following conclusions can be made for the researched variables:

- Complexity of illustration: by adding up the average values from all the respondents regarding the question about attractiveness, one can conclude that a more complex/a more detailed illustration was graded better (6o percent of respondents graded it attractive) than a simple one (55 percent of respondents graded it attractive).

- Product size: by adding up the average values from all the respondents regarding the question about attractiveness, one can conclude that the small product size is more attractive (6o percent of respondents graded it attractive) than the bigger product size (57 percent of respondents graded it attractive) as shown in Figure 2. It also shows that respondents tend to like ads that have products with secondary roles more than products with primary roles (which take a lot of ad space). The ads from the most efficient campaigns do not give the product a primary role. The message is more connected with people's lives, their habits, and their struggles than with the product itself. In this way, people can connect with the product (brand) more easily and can find a common ground between the product and themselves.

\section{Discussion}

Based on the research, it can be concluded that the combination of illustration and photographs is the combination that attracts the user's attention the most. The same combination has the highest possibility of being shared. Furthermore, this combination has the highest probability that the user will view the visual message longer than other variations. This in turn makes it easier for the user to comprehend the visual message and take the necessary action that is asked of him. With this, the first hypothesis of this paper is confirmed. If the visual message is understandable to the user, he/she will find it more attractive. Moreover, respondents would want to share the visual messages 
which they understood. With this, the second hypothesis is confirmed. It was thought that the length of the message affects the attractiveness of the visual message. Based on the research, the hypothesis that length affects a visual message's attractiveness is rejected.

As stated in the introduction section of this paper, to date there has been little or no research that address the visual parameters that show the relation between visual message's attractiveness and sharing outcome in the tourism industry. Mack et al. (2008), Zheng and Gretzel (2010), and Akehurst (2009) have stated that it is important to attract online user's attention but have not yet given quantitative research on attraction and its influence on sharing. In comparison to other research (Gaitho, 2018; Pfeil et al., 2009; Strano, 2008; Trammell \& Keshelashvili, 2005; Tussyadiah, 2012; Tussyadiah et al., 2011), which have provided valuable information regarding sharing, this paper has provided insight into parameters that attract online user's attention when shown visual messages for promotion purposes. As 42 per cent of Facebook users share the information about where they travel (Alizadeh \& Mat Isa, 2015), the knowledge from this paper will help companies in creating more efficient visual messages on social networks.

\section{Conclusion}

Illustrations enable additional manipulation with the visual message, which cannot be easily achieved just with photographs. In this way, the content of the message becomes more flexible and personal for the user.

Based on the research in this paper the following can be said for visual message's attractiveness.

A visual message is attractive if it has a complex/a detailed illustration besides a photograph, and if it has a small product size that does not interfere with other elements in the visual message. It is also noteworthy that respondents find the ad more attractive if the role of the product is secondary. In other words, content that takes a great part of the ad should be connected to the product and show something other than just a plain product picture. The most effective campaigns used in this research have also given their products a secondary role. The study has also shown that the length of the text inside the visual message does not af- fect the overall attractiveness for the user. Visual messages that were understandable for the user are more likely to be shared.

Based on this research, a visual message done in such a way will be shared by 18.57 per cent of users who have seen it.

By following these guidelines, marketers can improve the attractiveness of their visual messages for promotional activities. As marketers are already using different online tools for promotional activities (De Bruyn \& Lilien, 2008), the study of this paper can help them further increase the possibility for sharing content by making visual messages attractive. We are living in an age of intensive image sharing especially by young audiences whose income is higher than other groups, so knowing how to make visual messages attractive for them is crucial for promotional success in the travel industry.

Although this study has given insight into parameters of attraction for visual messages and its influence on online sharing, the study did not take specific platforms into consideration because of high burden for respondents.

In future research, we want to find a deeper understanding of the parameters that influence user's attractiveness, which were presented in this paper. By comparing visual messages on different platforms (desktop and mobile), we could further improve the study as today smartphones are a primary medium for online engagement. Furthermore, by researching different colour palettes it can be determined which dominant combinations and how many colours in a single visual message influence attractiveness. With this additional research, it can be found which colour contrast between more and less important information has the greatest impact on user's attention. This can give further insight into visual message effectiveness for promotional purposes.

\section{References}

Akehurst, G. (2009). User generated content: The use of blogs for tourism organisations and tourism consumers. Service Business, 3(1), 51-61.

Alizadeh, A., \& Mat Isa, R. (2015). The use of social media in destination marketing: An exploratory study. Turizam, $63(2), 175-192$. 
Axup, J., \& Viller, S. (2005). Augmenting travel gossip: Design for mobile communities. In A. Donaldson (Ed.), Proceedings of 2005 Australasian Computer-Human Interaction Conference, OZCHI 2005 (p. 4). New York, NY: ACM.

Bamford, W., Coulton, P., \& Edwards, R. (2007). Space-time travel blogging using a mobile phone. In M. Inakage, N. Lee, \& M. Tscheligi (Eds.), Proceedings of the International Conference on Advances in Computer Entertainment Technology (pp. 1-8). New York, NY: ACM.

Bortree, D. S. (2005). Presentation of self on the web: An ethnographic study of teenage girls' weblogs. Education, Communication and Information, 5(1), 25-39.

Boyd, D. (2008). Why youth (heart) social network sites: The role of networked publics in teenage social life. In D. Buckingham (ed.), Youth, identity, and digital media (pp. 119-142), Cambridge, ma: The Miт Press.

Boyd, D. M., \& Ellison, N. B. (2007). Social network sites: Definition, history, and scholarship. Journal of ComputerMediated Communication, 13(1), 210-230.

Bullas, J. (2012). 5 reasons why Facebook drives consumer buying - infographic. Retrieved from http://www .jeffbullas.com/5-reasons-why-facebook-drives -consumer-buying-infographic/

Cheverst, K., Davies, N., Mitchell, K., Friday, A., \& Efstratiou, C. (200o). Developing a context-aware electronic tourist guide: Some issues and experiences. In T. Turner, \& G. Szwillus (Eds.), CHI 2000 Proceedings of the SIGCHI Conference on Human Factors in Computing Systems (pp. 17-24). New York, NY: ACM.

De Bruyn, A., \& Lilien, G. L. (2008). A multi-stage model of word-of-mouth influence through viral marketing. International Journal of Research in Marketing, 25(3), 151163.

De Silva, K. (2018, 10 January). 9 mobile marketing trends you need to know for 2018. Retrieved from https://www .entrepreneur.com/article/306923

Edensor, T. (2000). Staging tourism: Tourists as performers. Annals of Tourism Research, 27(2), 322-324.

English, J. (2018, 30 January). Don't get left behind by the new online advertising standards. Retrieved from https:// www.entrepreneur.com/article/308083

Gaitho, M. (2018, 12 September). What is the real impact of social media? Retrieved from https://www.simplilearn .com/real-impact-social-media-article

Goodman, E. (2007). Destination services: Tourist media and networked places (U с в iSchool Report 2007-004). Retrieved from http://www.escholarship.org/uc/item/ o919c6sv
Grubb, E. L., \& Grathwohl, H. L. (1967). Consumer selfconcept, symbolism and market behaviour: A theoretical approach. Journal of Marketing, 31(4), 22-27.

Halevy, E. (2018, 2 February). 9 strategies for memorable advertising when your audience is chronically distracted. Retrieved from https://www.entrepreneur.com/article/ 306161

Heine, C. (2014, 2 October). Mobile vs. desktop: See which medium wins in 5 key comparisons. Retrieved from http://www.adweek.com/digital/mobile-vs-desktop-see -which-medium-wins-5-key-comparisons-160458/

Kietzmann, J. H., Hermkens, K., McCarthy, I. P., \& Silvestre, B. S. (2011). Social media? Get serious! Understanding the functional building blocks of social media. Business Horizons, 54(3), 241-251.

Kučiš, V. (2010). Translation tools as contributors to translation quality. Informatologia, 43(1), 19-33.

Kučiš, V. (2016). Translatologija u teoriji i praksi. Zagreb, Croatia: Hrvatsko komunikološko društvo.

Kumar, A., Bezawada, R., Rishika, R., Janakiraman, R., \& Kannan, P. K. (2016). From social to sale: The effects of firm-generated content in social media on customer behavior. Journal of Marketing, 8o(1), 7-25.

Larsen, J., Urry, J., \& Axhausen, K. (2006). Mobilities, networks, geographies. Aldershot, England: Ashgate.

Leenders, R. T. A. J. (2002). Modeling social influence through network autocorrelation. Social Networks, 24, 21-47.

Lo, I. S., McKercher, B., Lo, A., Cheung, C., Law, R. (2011). Tourism and online photography. Tourism Management, 32(4), 725-731.

Mack, R. W., Blose, J. E., \& Pan, B. (2008). Believe it or not: Credibility of blogs in tourism. Journal of Vacation Marketing, 14(2), 133-144.

Manyika, J., Chui, M., Brown, B., Bughin, J., Dobbs, R., Roxburgh, C., \& Byers, A. H. (2011). Big data: The next frontier for innovation, competition, and productivity. Washington, DC: McKinsey Global Institute.

McCabe, S., \& Stokoe, E. H. (2004). Place and identity in tourists' accounts. Annals of Tourism Research, 31(3), 601-622.

Mhlanga, O., \& Tichaawa, T. M. (2017). Influence of social media on customer experiences in restaurants: A South African study. Tourism: An International Interdisciplinary Journal, 65(1), 45-60.

Miller, A., \& Edwards, W. (2007). Give and take: A study of consumer photo-sharing culture and practice. In B. Begole (Ed.), CHI 2007 Proceedings (pp. 347-356). New York, NY: ACM.

Newlands, M. (2018, 13 March). The dominance of mobile 
marketing is complete. Retrieved from https://www .entrepreneur.com/article/290384

Osborne, P. (200o). Travelling light: Photography, travel and visual culture. Manchester, England: Manchester University Press.

Pan, B., MacLaurin, T., \& Crotts, J. C. (2007). Travel blogs and the implications for destination marketing. Journal of Travel Research, 46(1), 35-45.

Pfeil, U., Arjan, R., \& Zaphiris, P. (2009). Age differences in online social networking: A study of user profiles and the social capital divide among teenagers and older users in MySpace. Computers in Human Behavior, 25(3), 643-654.

Qian, H., \& Scott, C. R. (2007). Anonymity and self-disclosure on weblogs. Journal of Computer-Mediated Communication, 2(4), article 14.

Schroeder, J. E. (2002). Visual consumption. London, England: Routledge.

Schmallegger, D., Carson, D., \& Jacobsen, D. (2010). The use of photographs of consumer generated content websites: Practical implications for destination image analysis. In N. Sharda (Ed.), Tourism informatics (pp. 243-260), Hershey, PA: IGI Global.

Sontag, S. (1977). On photography. London, England: Penguin.

Singh, P. (2018). The blogger's guide to understanding the psychology of social networks. Retrieved from https:// bloggingwizard.com/psychology-of-social-networks/

Strano, M. M. (2008). User descriptions and interpretations of self-presentation through Facebook profile images. Cyberpsychology: Journal of Psychosocial Research on Cyberspace, 2(2). Retrieved from https://cyberpsychology .eu/article/view/4212/3253
Trammell, K. D., \& Keshelashvili, A. (2005). Examining the new influencers: A self presentation study of A-list blogs. Journalism and Mass Communication Quarterly, 82(4), 968-982.

Tussyadiah P. (2012). A concept of location-based social network marketing. Journal of Travel \& Tourism Marketing, 29(3), 205-220.

Tussyadiah, I. P., Park, S., \& Fesenmaier, D. R. (2011). Assessing the effectiveness of consumer narratives for destination marketing. Journal of Hospitality \& Tourism Research, 35(1), 64-77.

Večernji list. (2018, 23 February). Jedan tweet Kylie Jenner srušio vrijednost Snapchata za 1,7 milijarda dolara. Retrieved from https://www.vecernji.hr/techsci/jedan -tweet-kylie-jenner-srusio-vrijednost-snapchata-za-1 -7-milijarda-dolara-1228299

Wilton, R. D., Páez, A., \& Scott, D. M. (2011). Why do you care what other people think? A qualitative investigation of social contact and telecommuting. Transportation Research Part A: Policy and Practice, 45(4), 269-282.

Zheng, X., \& Gretzel, U. (2010). Role of social media in online travel information search. Tourism Management, 31, 179-188.

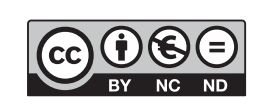

This paper is published under the terms of the Attribution- NonCommercial-NoDerivatives 4.0 International (CC B Y-NC-ND 4.0) License. 